\title{
Pra Desain Pabrik Pemanfaatan Gas Alam Natuna Menjadi Dietil Karbonat Melalui Proses

\author{
Direct Synthesis
}

\author{
Lukas Rudy Paembong, Yesaya Reuben Natanael, Annas Wiguno, dan Gede Wibawa \\ Departemen Teknik Kimia, Fakultas Teknologi Industri, Institut Teknologi Sepuluh Nopember (ITS) \\ Jl. Arief Rahman Hakim, Surabaya 60111 Indonesia \\ e-mail: gwibawa@chem-eng.its.ac.id
}

\begin{abstract}
Abstrak-Konsumsi bahan bakar minyak yang terus meningkat menyebabkan polusi $\mathrm{CO}_{2}$. Eksplorasi dan pemanfaatan gas alam, seperti pada Natuan Gas field, akan menghasilkan banyak emisi $\mathrm{CO}_{2}$. Pada penelitian ini telah dilakukan perancangan pabrik Dietil Karbonat dengan bahan baku $\mathrm{CO}_{2}$ dimana kapasitas produk DEC sebesar 10.565.449 ton/tahun dan sales gas sebesar 45.299.932 MMBtu/tahun, dengan umur pabrik 20 tahun yang berjalan kontinyu selama 330 hari / tahun. Tujuan perancangan pabrik dietil karbonat adalah untuk memanfaatkan $\mathrm{CO}_{2}$ dari hasil gas alam pada Natuna gas field. Pabrik dietil karbonat direncanakan didirkan pada Kepulauan Natuna, Provinsi Kepulauan Riau. Tempat ini dipilih karena tersedia akses terhadap bahan baku utama berupa gas alam pada perairan Natuna, sarana transportasi darat dan laut, ketersediaan listrik, air dan pemasaran produk dapat dilakukan pada daerah Balikpapan, dan luar negeri melalui Singapura. Pada pabrik ini digunakan proses direct synthesis menggunakan bahan baku $\mathrm{CO}_{2}$, etanol, dan etilen oksida dimana katalis KI dan sodium etoksida digunakan dalam proses sintesa. Produk samping dari proses ini ialah etilen karbonat (4.319.760 ton/tahun), etilen gilkol (5.501.320 ton / tahun) dan cellosolve (846.776,7 ton/tahun) yang memiliki nilai jual yang baik. Secara analisis ekonomi didapatkan total investment cost : 25.047,69 Juta USD, net pressent value : 148,121 juta USD, IRR : 35,84\%, dan POT : 3,611 tahun sehingga pabrik pemanfaatan gas alam pada Natuna gas field perlu dipertimbangkan
\end{abstract}

Kata Kunci- $\mathrm{CO}_{2}$, Dietil Karbonat, Desain Pabrik, Etanol

\section{PENDAHULUAN}

$\mathrm{E}^{\prime}$ NERGI merupakan kebutuhan pokok pada negara berkembang. Bahan bakar minyak (BBM) berbasis fosil adalah salah satu sumber energy yang banyak digunakan pada dunia industri dan transportasi. Data menunjukan konsumsi bahan bakar minyak tercatat 70.744.977 KL pada tahun 2014 [1]. Konsumsi bahan bakar minyak yang secara terus menerus menghasilkan $\mathrm{CO}_{2}$ dimana emisi $\mathrm{CO}_{2}$ meningkat setiap tahunnya. $\mathrm{CO}_{2}$ adalah salah satu dari gas rumah kaca yang dapat menyebabkan pemanasan global. Penggunaan additive dipercaya dapat mengurangi emisi. Senyawa yang lazim digunakan adalah tetra ethyl lead dan tetra methyl lead, akan tetapi penggunaan kedua senyawa dapat bersifat racun dan merusak control emisi. Maka dikembangkan suatu bahan aditif lain yaitu senyawa oxygenate seperti methyl-tertiary-buthyl ether (MTBE), akan tetapi MTBE dan senyawa alcohol memiliki kelarutan yang tinggi dalam air dan alcohol membuat bahan bakar memiliki tekanan uap yang tinggi [2]. Additif lain yang dikembangkan adalah dietil karbonat (DEC). DEC memiliki kandungan oksigen hingga 40,6\% dan penggunaannya sebesar 5\% dapat mengurangi partikulat sebesar $50 \%$. Senyawa DEC juga ramah lingkungan[3].

Pengembangan energy baru, seperti gas alam, menjadi salah satu pokok sumber energy. Natuna gas field memiliki potensi untuk menjadikan sumber energy gas alam. Gas alam natuna memiliki molar rate 500 MMCFD (21.665 Ton/hari) dengan tekanan gas 56,86 bar dan temperature $37,78 \mathrm{oC}$. Akan tetapi, tingkat $\mathrm{CO}_{2}$ yang mencapai $71,22 \%$ menjadi masalah tersendiri. Maka diperlukan suatu cara untuk memanfaatkan $\mathrm{CO}_{2}$ yaitu dengan menjadikan $\mathrm{CO}_{2}$ sebagai bahan baku pembuatan dietil karbonat dengan mensintesakannya dengan etanol dan etilen karbonat melalui direct synthesis. Kajian studi pra desain pabrik untuk sintesa DEC dari $\mathrm{CO}_{2}$ sebelumnya mencoba menggunakan indirect route dengan katalis $\mathrm{CeO}_{2}$, akan tetapi memiliki yield reaksi yang lebih kecil [4]. Studi terakhir menunjukan bahwa hasil terbaik yang tercapai berupa : 63,6\% dari yield DEC dan $68,5 \%$ dari yield glikol (produk samping) dimana 97,5\% konversi Ethylene oxide (EO) bisa tercapai pada $443 \mathrm{~K}$ dan $3 \mathrm{MPa} \mathrm{CO} 2$ tekanan awal dalam waktu operasi 3 jam[5].

\section{II.URAIAN PROSES}

Proses produksi DEC dari etanol dan $\mathrm{CO} 2$ menggunakan gas alam natuna terbagi dalam dua tahapan yaitu pemurnian $\mathrm{CO} 2$ dan tahap sintesa CO2. Sintesa DEC dilakukan dengan mengunakan $\mathrm{CO}$, etilen oksida, dan etanol, menggunakan katalis KI dan sodium etoksida. Secara umum kedua tahapan proses terbadi menajadi empat bagian yaitu:

1. Unit Pemisahan $\mathrm{CO} 2$

2. Unit Sintesa

3. Unit Pemisahan Produk

4. Unit Purifikasi Produk

Proses memiliki tahapan yang berbeda beda, namun secara garis besar dapat digambarkan sesuai flowchart pada gambar I

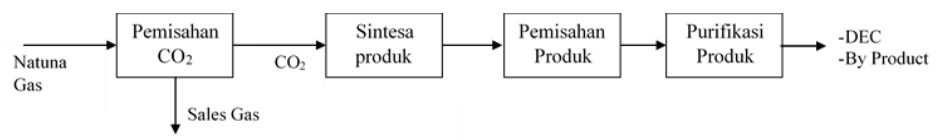

Gambar 1. Blok Diagram Proses Pembentukan DEC

\section{A. Unit Pemisahan $\mathrm{CO} 2$}

Proses purifikasi diperlukan karena gas alam yang mengandung $\mathrm{CO}_{2}$ dan sales gas harus dipisahkan. Pada tahap awal ini gas yang dihasilkan di Natuna diolah terlebih dahulu untuk mendapatkan gas $\mathrm{CO}_{2}$ murni melalui teknologi membran. Feed berupa keluaran berupa campuran gas 
mengandung $71,22 \% \mathrm{CO}_{2}, 1,43 \% \mathrm{H}_{2} \mathrm{~S}, 27,18 \% \mathrm{CH}_{4}, 0,14 \%$ $\mathrm{C}_{2} \mathrm{H}_{6}, 0,02 \% \mathrm{C}_{3} \mathrm{H}_{8}$, dan $0,01 \% \mathrm{C}_{4} \mathrm{H}_{10}$ dialirkan ke membran untuk memurnikan $\mathrm{CO}_{2}$ sebelum masuk ke proses DEC dan juga memurnikan gas alam untuk diolah menjadi Sales Gas. Dari membran ini, dihasilkan gas alam dalam aliran dengan komposisi 4,74\% $\mathrm{CO}_{2}, 89,95 \% \mathrm{CH}_{4}$ dan beberapa senyawa kimia kandungan Sales Gas, sedangkan aliran $\mathrm{CO}_{2}$ yang siap diolah menjadi DEC menghasilkan 99,81\% $\mathrm{CO}_{2}$ dan $0,19 \%$ $\mathrm{CH}_{4}$. Kemudian aliran ke pengolahan DEC diturunkan tekanannya menjadi 35 bar, mendekati kondisi operasi di reactor pengolahan DEC dan meningkatkan suhu fluida dari $13,67{ }^{\circ} \mathrm{C}$ menjadi $169{ }^{\circ} \mathrm{C}$ sama dengan suhu operasi pada reaktor DEC. Aliran mengandung sales gas dimurnikan kembali dalam absorber dengan menggunakan MDEA sebagai absorbent dengan tujuan menurunkan kadar $\mathrm{CO}_{2}$. Hasil produk atas masuk ke dalam separator menghasilkan produk berupa Sales Gas dengan kandungan 98,47\% $\mathrm{CH}_{4}$, $0,88 \% \mathrm{CO}_{2}, 0,08 \% \mathrm{H}_{2} \mathrm{O}, 0,48 \% \mathrm{C}_{2} \mathrm{H}_{6}, 0,06 \mathrm{C}_{3} \mathrm{H}_{8}$, dan $0,02 \%$ $\mathrm{C}_{4} \mathrm{H}_{10}$. Aliran yang kaya akan Amine dengan kandungan 49,47\% MDEA, 49,02\% $\mathrm{H}_{2} \mathrm{O}$ dan sedikit kandungan lainnya menuju kolom distilasi untuk diolah dan di-recycle ke dalam kolom absorber.

\section{B. Unit Sintesa}

Pada tahap sintesa DEC yang menggunakan reaksi langsung dimana reaksi terjadi pada suhu $169{ }^{\circ} \mathrm{C}$ dan tekanan 30 bar. Pengaruh katalis telah diteliti pada kondisi operasi yang serupa sesuai pada Tabel I. [5]

Tabel 1.

Jenis Katalis dan Yield DEC

\begin{tabular}{|c|c|c|c|}
\hline \multicolumn{2}{|c|}{ Jenis Katalis } & \multirow{2}{*}{$\begin{array}{c}\text { Konversi etilen } \\
\text { Oksida (\%) }\end{array}$} & \multirow{2}{*}{ Yield (\%) } \\
\hline I & II & & \\
\hline $\mathrm{KI}$ & & 97,3 & 20,6 \\
\hline $\mathrm{KI}$ & $\mathrm{CeO}_{2}$ & 94,2 & 8,9 \\
\hline $\mathrm{KI}$ & Sodium Etoksida & 97,2 & 30,8 \\
\hline
\end{tabular}

Maka reaksi menggunakan dual katalis $\mathrm{KI}$ dan sodium etoksida. Feed dari hasil pemisahan $\mathrm{CO}_{2}$ dicampurkan dengan aliran yang mengandung Ethylene oxide dan aliran hasil recycle yang mengandung 93,32\% etanol, 6,48\% $\mathrm{H}_{2} \mathrm{O}$, dan $0,19 \%$ Ethylene oxide. Terjadi 3 reaksi dengan konversi yang berbeda. Reaksi digambarkan dalam Gambar II. ${ }^{[5]}$

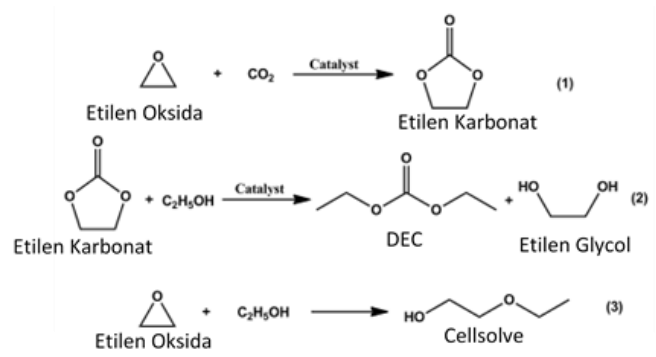

Gambar 2. Reaksi Pembentukan DEC

Pada reaksi pertama dihasilkan Ethylene carbonate (1) saat $\mathrm{CO}_{2}$ bereaksi dengan Ethylene oxide dengan konversi sebesar $92,5 \%$ dan pada reaksi kedua (2) Ethylene carbonate akan ditransesterifikasi oleh etanol untuk menjadi DEC dan Ethylene Glycol dengan konversi $12,72 \%$ Ethylene carbonate. Reaksi ketiga (3) juga terjadi di reaktor ini dengan konversi yang kecil mengahasilkan Cellosolve. Hasil keluaran dari reaktor dalam fase liquida memiliki komposisi
78,24\% etanol, 6,27\% $\mathrm{H}_{2} \mathrm{O}, 5,75 \%$ DEC, 5,74\% Ethylene Glycol, 3,12\% Ethylene carbonate, 0,57\% Cellosolve, $0,28 \%$ Ethylene oxide.

\section{Unit Pemisahan Produk}

Tujuan dari pemisahan produk adalah untuk memisahkan produk dari etanol pada kolom distilasi. Aliran yang telah keluar dari reaktor akan memasuki tahap separasi. Aliran produk reaktor sebelumnya diturunkan suhunya hingga suhu 70oC dan tekanannya diturunkan hingga 9,7 bar yang dimaksudkan untuk mengurangi biaya pada kolom separasi dan menjaga keamanan pekerja. Pada kolom distilasi 1, yang memiliki 20 stage dengan aliran feed pada stage 10 , top product, yang kaya akan ethanol dapat langsung di recycle dan akan diproses sembelum diumpankan kembali ke dalam reaktor. Sedangkan bottom product yang kaya akan DEC, EC, E-glycol, serta Cellosove akan dipisahkan lebih lanjut pada tahapan berikutnya. Aliran bottom product mengalami penurunan tekanan hingga berada pada tekanan 2,5 bar dan menuju three phase separator menghasilkan tiga aliran. Aliran vapor dan aliran yang kaya akan ethylene carbonate menuju kolom distilasi 2, yang memiliki 25 stage dan aliran feed masuk pada stage 13, dimana top product distiliasi akan menuju proses purifikasi Ethlene Glycol. Sedangkan bottom product merupakan aliran ethylene carbonate $99,99 \%$. Aliran terakhir dari three phase separator akan menuju kolom distilasi 3, yang memiliki 20 stage dimana feed masuk apda stage 9, dimana top product merupakan aliran yang kaya akan DEC dan Cellosove dan menuju unit purifikasi DEC. Sedangkan bottom product yang kaya akan Ethylene Glycol akan memasuki unit purifikasi ethylene glycol.

\section{Unit Purifikasi Produk}

Proses purifikasi produk terbagi menjadi dua bagian yaitu purifikasi DEC dan purifikasi ethylene glycol. Pada purifikasi ethylene glycol, aliran yang kaya akan etilen glikol akan memasuki kolom distilasi 4, dimana feed masuk pada stage 13 dari 25 stage, memiliki bottom produk yaitu aliran kaya akan etilen glikol dan etilen karbonat namun tidak saling larut. Aliran bottom product distilasi 4 akan dipisahkan pada decanter sehingga menjadi dua aliran kaya akan etilen karbonat dan etilen glikol. Sedangkan top product distilasi 4 akan menuju kolom distilasi 5 bercampur dengan aliran kaya akan DEC dan cellosolve dari hasil unit separasi. Distilasi 5 memiliki 57 stage dengan aliran feed masuk pada stage 29. Top product distilasi 5 adalah aliran kaya akan DEC 99,57\%, dan bottom product adalah aliran kaya akan cellosolve dengan kemurnian 99,92\%. Semua aliran akan didinginkan hingga mencapai suhu kamar.

\section{NERACA MASSA}

Berdasarkan hasil perhitungan neraca massa, dengan feed rate gas alam natuna sebesar 500 MMCFD (21.665 ton/hari), etanol 31.285,69 ton/hari, dan etilen oksida 19.772 ton/hari akan menghasilkan produk berupa DEC 32.016,51 ton/hari, Cellosolve 2.565,99 ton/hari, Etilen Glikol 16.670,67 ton/hari, dan etilen karbonat 13.090,18 ton/hari serta sales gas sebesar 45.299.932 MMBtu/ tahun.

\section{ANALISIS EKONOMI}

Berdasarkan hasil perhitungan dengan neraca ekonomi, didaptkan total investment cost sebesar 25.047,69 Juta USD 
dengan bunga $12 \%$ per tahun dimana BEP mencapai $30,688 \%$, Net Pressent Value : 148,121 juta USD, dan IRR sebesar $35,84 \%$. Dengan estimasi umur pabrik mencapai 20 tahun, pabrik beroperasi 24 jam untuk 330 hari/ tahun, dan periode pembangunan selama 2 tahun, maka diperkirakan dibutuhkan 3,611 tahun untuk pengembalian modal.

\section{V.KESIMPULAN}

Pabrik yang berlokasi pada kepulauan Natuna, Provinsi Kepulauan Riau memiliki IRR berada pada 35,84\%, dimana nilai ini lebih tinggi dari suku bank (12\% / tahun), dan pengembalian modal selama 3,611 tahun. Maka pabrik dietil karbonat dari $\mathrm{CO}_{2}$ melalui proses direct synthesis pada natuna gas field layak didirikan.

\section{DAFTAR PUSTAKA}

[1] Statistik Migas. 2015. Data Statistik. Direktorat Jenderal Minyak dan Gas Bumi, Kementrian Energi dan Sumber Daya Mineral 18 Oktober 2017

[2] Tanusha, T.K., Ramesh, R., Fazli, A.S.N.A., Yunus, M.Y.M., dan Ramesh, K. 2016. Measurement and Prediction of Fuel Oxygenates Mixtures Excess Thermophysical Properties - a Review. Engineering and Applied Sciences. 11, 2639-2646

[3] Roh, N-S., Dunn, B.C., Eyring, E.M., Pugmire, R.J., dan Meuzelaar H.L.C. 2003. Production of Diethyl Carbonate from Ethanol dan Carbon Monoxide over a Heterogenous Catalytic Flow Reactor. Fuel Processing Tech. 83, 27-38

[4] Rachmawati, D., Widi, R.A., dan Wibawa, G. 2017. Pra Desain Pabrik Dietil Karbonat dari $\mathrm{CO}_{2}$ dan Ethanol Melalui Proses Indirect Route. Jurnal Teknik ITS (6), ISSN : 2337-3539 (23019271 print)

[5] Wang, L., Li, H., Xin, S., He, P., Cao, Y., Li, F., dan Hou, X. 2014. Highly Efficient Syhtesis of Diethyl Carbonate via one-pot Reaction from Carbon Dioxide, Epoxides and Ethanol over KI-based Binary Catalysts System. Elsevier, Journal Applied Catalysis A : General 471, 19-27 